\title{
Colorimetric and sensory characteristics of fermented cured sausage with Brazilian ostrich meat addition
}

\author{
Carlos Pasqualin CAVALHEIRO ${ }^{1 *}$, Natiéli PIOVESAN ${ }^{1}$, Lisiane de Marsillac TERRA ${ }^{1}$, \\ Maristela LOVATO ${ }^{1}$, Nelcindo Nascimento TERRA ${ }^{1}$, Leadir Lucy Martins FRIES ${ }^{1}$
}

\begin{abstract}
The aim of this study was to determine the colorimetric and sensory characteristics of a fermented cured sausage containing ostrich meat (Struthio camelus) and pork meat. Four treatments were performed: one with no ostrich meat (TC) and the others containing 19.08 (T1), 38.34 (T2), and 57.60\% (T3) of ostrich meat and pork meat. Colorimetric analyses were measuring $L^{*}, a^{*}$, $b^{\star}, C^{*}$, and $h^{\circ}$. Sensory analysis was conducted assessing color, aroma, flavor, and texture at the end of the sausages' processing. The sausages containing ostrich meat were statistically different from the control in the instrumental colorimetric analysis. In the sensory analysis, no significant differences were observed between the treatments for aroma, flavor, and texture. However, significant differences were found in the color of the sausages due to the high myoglobin content present in the ostrich meat, which resulted in a very dark color in the treatment with the highest percentage of this type of meat.
\end{abstract}

Keywords: ostrich meat; salami; color; sensory evaluation.

\section{Introduction}

In recent years the interest in breeding ratites such as ostriches and rhea has been growing. The commercial farming of these birds has attracted the attention of new breeders, and it has become a great alternative to rural production. Although ostriches were originally domesticated for the harvesting of their feathers, which was followed by high prices being paid for their skins, nowadays they are farmed to provide healthy red meat (COOPER; HORBANCZUK, 2002). In Brazil, this activity started by importing ostriches from South Africa and the United States. In Europe, breeding ostriches as livestock for hide and meat started more than 20 years ago (CARBAJO, 2005).

Currently, there is a growing concern over healthy foods. Thus, the consumption of low-fat meats which are nutritious and tasty has been encouraged by physicians and health professionals (HOFFMAN; MELLET, 2003). Accordingly, ostrich meat production has captured world attention, which led to an increased consumption of this meat in the mid-2000's. Ostriches produce red meat that is similar in flavor and texture to beef (SALES, 1996; SALES; HORBANCZUK, 1998).

Ostrich meat is characterized by high $\mathrm{pH}$ and a dark color related to high pigment content, high levels of polyunsaturated fatty acids, and low levels of saturated fatty acids (PICALLO et al., 2004). Furthermore, this kind of meat is highly perishable due to its high $\mathrm{pH}$ and the need for more research on the use of ostrich meat in value added products is evident. Some authors have reported that ostrich meat can be used successfully in cooked sausages (FERNÁNDEZ-LOPEZ et al., 2003; FISHER; HOFFMAN; MELLET, 2000), fresh sausages (NASCIMENTO et al., 2012), and in Italian-type fermented sausages (BÖHME et al., 1996). At the same time, ostrich meat represents a good alternative as a raw material to produce cured sausages although, due to its low fat content, some manufacturers add pork meat and fat to these products to improve masticability, juiciness, aroma, and taste (SORIANO et al., 2007).

Fermented cured sausages are ready-to-eat foods; microbiological safety of this type of products is essentially ensured by a decrease in $\mathrm{pH}$ (4.5-5.0) and in water activity below minimum growth limit for most pathogens, thus enabling a more efficient bacterial control in a 'hurdle technology' concept (BARBUTI; PAROLARI, 2002). Visual appearance and color are important factors in determining consumers' selection of food. During the fermentation stage, sausages become red (cured color) due to the production of nitrosomyoglobin resulting from the combination of nitric oxide (NO), formed by the bacterial conversion of nitrate to nitrite, and myoglobin. The products gradually darken through the maturation process (CURT et al., 2004).

Sensory quality of products is one of the most important factors that attract consumers. It results from a number of aspects such as flavor (taste and aroma), texture, and color. The typical salami flavor is produced through a complex process involving carbohydrates fermentation, proteolysis, lipolysis, lipid oxidation, spices, curing salts, and others (DEMEYER et al., 2000). This sensory quality depends on the combination of some factors related to processing conditions, materials, storage, and facilities used (CURT et al., 2004). Therefore, the aim of this study was to evaluate the colorimetric $\left(L^{*}, a^{*}, b^{*}, C^{*}\right.$, and $\left.h^{o}\right)$ and sensory characteristics (color, aroma, flavor, and texture) of fermented cured sausages prepared with different amounts of ostrich meat mixed with pork meat.

Received 6/17/2013

Accepted 8/19/2013 (006145)

${ }^{1}$ Programa de Pós-graduação em Ciência e Tecnologia dos Alimentos, Universidade Federal de Santa Maria - UFSM, Av. Roraima, 1000, Prédio 42, Camobi, CEP 97105-900, Santa Maria, RS, Brasil, e-mail: cavalheiro.carlos@hotmail.com

${ }^{*}$ Corresponding author 


\section{Materials and methods}

\subsection{Samples}

One year old ostriches weighing approximately $115 \mathrm{Kg}$ were slaughtered. In the present study, the ostrich M. iliofibularis was used; it was kindly donated by a breeding association located in the central region of Rio Grande do Sul state. The pork meat (arm shoulder) was chosen following the industry standard formulation, and it was purchased from a local commercial establishment.

\subsection{Preparation of fermented cured sausages}

Four treatments were used to evaluate the influence of ostrich meat on the color and sensorial characteristics of fermented cured sausages. The sausages were made in a pilot plant at the Federal University of Santa Maria (Brazil). Table 1 shows the fermented cured sausages formulation, which consisted of four treatments with different pork and ostrich meat amounts and some other ingredients such as pork fat, sodium chloride, sodium nitrate, sodium nitrite, sodium ascorbate, glucose, garlic, sucrose, ground pepper, and a commercial starter culture (Germinal ${ }^{\circ}$, São Paulo, Brazil) containing Lactobacillus plantarum (50\%) and Staphylococcus xylosus (50\%). The amount of mixture used was $10^{6}-10^{7} \mathrm{cfu} . \mathrm{kg}^{-1}$. Two independent replicates of each treatment were performed.

The sausages were prepared according to the standard procedure for Italian-type salami (TERRA, 1998). Five kilograms of mixed meat of each different treatment were elaborated and stuffed into a $60 \mathrm{~mm}$ artificial collagen casing (Viscofan ${ }^{\circ}$, Naturin, Weinheim, Germany) and cut in slices of approximately $10 \mathrm{~cm}$ length. After being stuffed, the samples were placed in a $20 \%$ potassium sorbate solution and ripened in a laboratory ripening cabinet (Menoncin ${ }^{\circ}$, Menoncin, Erechim, Brazil) for 28 days, until reaching water activity of 0.87 . Temperature and relative humidity were programmed (To/\%RH) as follows: first day, temperature $25^{\circ} \mathrm{C} / \mathrm{R} . \mathrm{H} 95 \%$; second day, $24{ }^{\circ} \mathrm{C} / 93 \%$, third day, $23{ }^{\circ} \mathrm{C} / 90 \%$, fourth day, 22 ${ }^{\circ} \mathrm{C} / 85 \%$, fifth day, $21{ }^{\circ} \mathrm{C} / 80 \%$, sixth day, $20{ }^{\circ} \mathrm{C} / 75 \%$, and from the seventh day onwards, $18^{\circ} \mathrm{C} / 75 \%$.

Table 1. Formulation of fermented cured sausages prepared with different concentrations of ostrich meat mixed with pork meat (\%).

\begin{tabular}{lcccc}
\hline \multirow{2}{*}{ Ingredients } & \multicolumn{4}{c}{ Treatments } \\
\cline { 2 - 5 } & TC & T1 & T2 & T3 \\
\hline Ostrich meat & - & 19.08 & 38.34 & 57.60 \\
Pork meat & 76.68 & 57.60 & 38.34 & 19.08 \\
Pork fat & 19.00 & 19.00 & 19.00 & 19.00 \\
Sodium chloride & 2.50 & 2.50 & 2.50 & 2.50 \\
Sodium nitrate & 0.15 & 0.15 & 0.15 & 0.15 \\
Sodium nitrite & 0.15 & 0.15 & 0.15 & 0.15 \\
Sodium ascorbate & 0.20 & 0.20 & 0.20 & 0.20 \\
Glucose & 0.40 & 0.40 & 0.40 & 0.40 \\
Garlic & 0.30 & 0.30 & 0.30 & 0.30 \\
Sucrose & 0.40 & 0.40 & 0.40 & 0.40 \\
Ground pepper & 0.20 & 0.20 & 0.20 & 0.20 \\
Starter culture & 0.02 & 0.02 & 0.02 & 0.02 \\
\hline
\end{tabular}

\subsection{Determination of colorimetric parameters}

Color parameters were determined in triplicate with a Chroma Meter (Minolta ${ }^{\circledR}$ Camera Co. LTD, CR-300, Osaka, Japan), which uses the CIE $L^{*} a^{*} b^{*}$ color system, by measuring lightness $\left(L^{*}\right)$, redness $\left(a^{*}\right)$, and yellowness intensities $\left(b^{*}\right)$. Aperture of $8 \mathrm{~mm}$, illuminant D65, and $10^{\circ}$ Standard observer were used (ANSORENA et al., 1997). Calibration was performed using a white standard plate $\left(L^{*}=95.26, a^{*}=0.89, b^{*}=1.18\right)$. Three measured color parameter were also converted into Chroma $C^{*}=\left[\left(a^{\star}\right)^{2}+\left(b^{*}\right)^{2}\right]^{1 / 2}$, which expresses color purity or saturation, and hue angle $h^{\circ}=\operatorname{arctangent}\left[b^{*} / a^{*}\right]$, which indicates the color nuances (GONCALVES et al., 2007; WROSLTAD; DURST; LEE, 2005). The $\mathrm{pH}$ was measured using a digital potentiometer (TERRA; BRUM, 1988) (Digimed, DM 20, São Paulo, Brazil).

\subsection{Sensory evaluation}

This study protocol was approved by the Research Ethics Committee of Federal University of Santa Maria, RS, Brazil (\#0303.0.243.000-10). All participants signed a consent form agreeing to voluntarily participate in the sensory analysis, and the tasting panel was composed of 32 untrained judges (53\% male and $47 \%$ female), who were consumers of salami. The Multiple Comparison Test was used in the sensory evaluation to determine if there is a significant difference $(p<0.05)$ between the different treatments and the standard sample (MEILGAARD; CIVILLE; CARR, 1999). A seven-point scale anchored by $1=$ extremely worse than the standard and $7=$ extremely better than the standard was used, in which 4 indicated no difference from the standard. The control treatment was also offered as a standard. The fermented cured sausages were sliced into $2 \mathrm{~mm}$ thick slices, and the parameters analyzed by the panelists were color, aroma, flavor, and texture. Sensory evaluation was performed by panelists in partitioned booths under incandescent lighting. Water and unsalted crackers were provided between samples as palate cleansers and to remove any residual flavors. The sensory analysis was carried out two days after the fermented cured sausages were ready.

\subsection{Statistical analysis}

A completely randomized design with four levels of ostrich meat was used $(0,19.08,38.34$ and $57.60 \%)$. The data were analyzed using analysis of variance (ANOVA), and the means were compared by the Tukey's test at a confidence level of 5\% using the SPSS statistical package (SPSS Inc., 9.0, Chicago, USA).

\section{Results and discussion}

\subsection{Colorimetric parameters}

As for the parameter lightness index $\left(L^{*}\right)$ (Table 2), the results showed a significant difference between the treatments and the control from the first day of elaboration (day 0). A pronounced decrease in the lightness level of the treatments was observed during the drying step, and an irregular behavior of these values was also observed during the first seven days of fermentation. After the end of the fermentation step (day 
Table 2. Mean values ( \pm standard deviation) of lightness $\left(L^{*}\right)$, redness $\left(a^{\star}\right)$, yellowness $\left(b^{\star}\right)$ intensity, chroma $\left(C^{\star}\right)$, hue angle $\left(h^{\circ}\right)$, and pH of fermented cured sausages produced with different concentrations of ostrich meat mixed with pork meat.

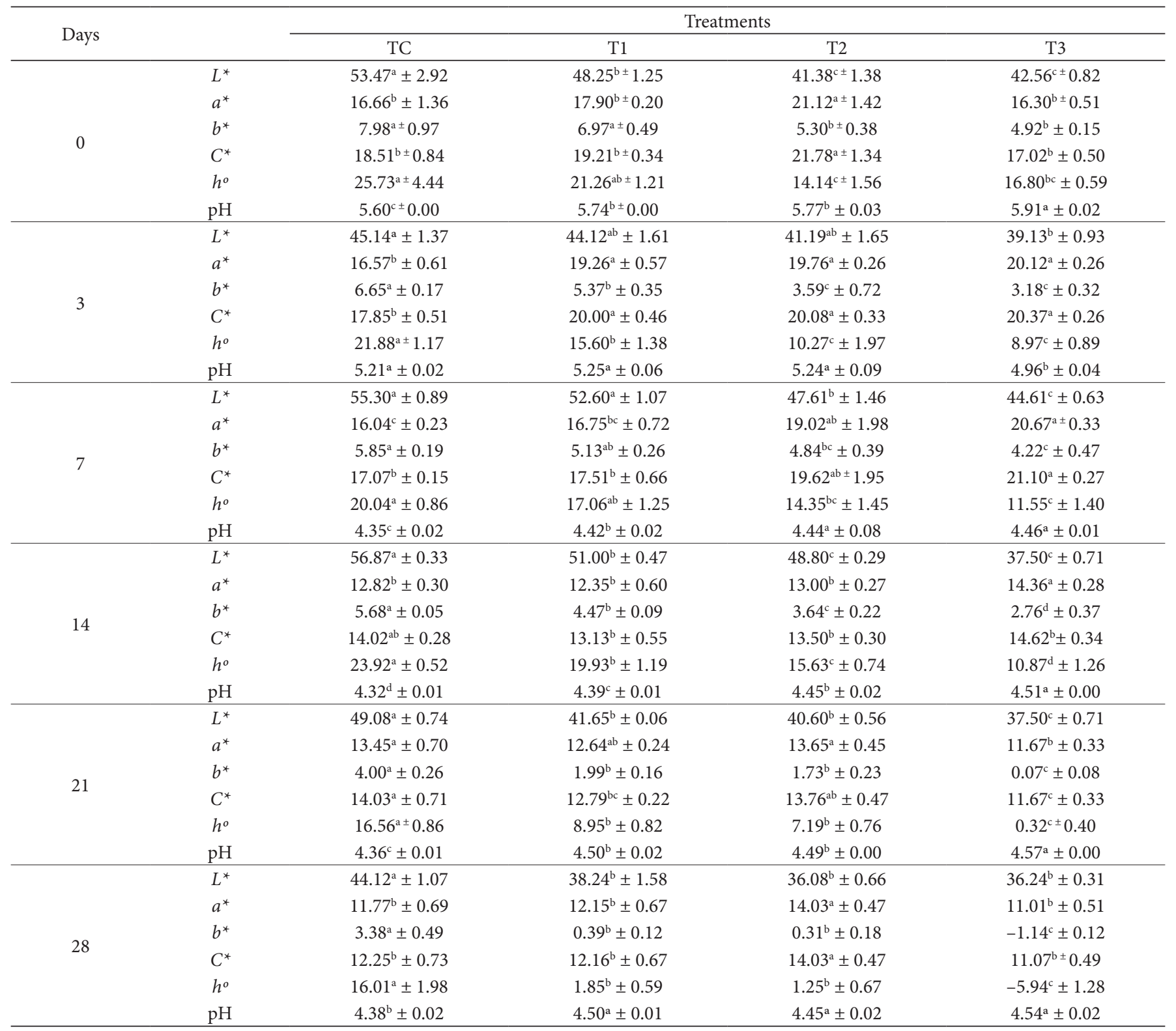

Values are given as mean $\pm \mathrm{SD}(\mathrm{n}=3)$. ${ }^{\mathrm{D}}$ Different letter within the same row indicate significant difference ( $\left.\mathrm{p}>0.05\right)$. Control treatment - with no addition of ostrich meat; $\mathrm{T} 1-$ addition of $19.08 \%$ of ostrich meat; T2 - addition of $38.34 \%$ of ostrich meat; T3 - addition of $57.60 \%$ of ostrich meat.

7), there was no statistical difference $(\mathrm{p}<0.05)$ between the control and the treatment containing $19.08 \%$ of ostrich meat (T1). However, as the concentration of ostrich meat increased, the lightness of the treatments decreased. In addition, between days 3 and 7, the $\mathrm{pH}$ dropped to values below 4.5, and it was an increase in the lightness index (BARBUT, 2010) could be observed. These changes in color are due to protein denaturation and coagulation caused by the acid production (NGAPO; WILKINSON; CHONG, 1996; BARBUT, 2005).

When the product was ready (day 28), a significant difference between the control and all treatments containing ostrich meat was observed, and at that time, the ostrich meat amount did not significantly influence $(\mathrm{p}<0.05)$ lightness rate. The mean value of lightness $\left(L^{*}\right)$ of the ostrich meat was 32.5 , and there were no differences among different muscles (MAJEWSKA et al., 2005). Another author found lightness values between 27.4 and 34.4, with significant differences among muscles, and $M$. fibularis longus was the darkest (HOFFMAN et al., 2008).

The lightness values obtained in the present study are in accordance with those of other studies (CHASCO; LIZASO; BERIAIN, 1996; KAYAARDI; GÖK, 2003; BOZKURT; BAYRAM, 2006; ERCOSKUN; ÖZKAL, 2011), in which high lightness values were found during fermentation and lower values were found during drying of fermented cured sausages made from different meats such as lamb, pork, and beef. In a study on ostrich meat sausage (yor), another author found 
Table 3. Multiple Comparison Test results of the mean values ( \pm standard deviation) of the scores obtained for color, aroma, flavor, and texture of the sausages produced with different concentrations of ostrich meat.

\begin{tabular}{ccccc}
\hline \multirow{2}{*}{ Parameters } & \multicolumn{3}{c}{ Treatments } \\
\cline { 2 - 5 } & TC & T1 & T2 & $2.75^{\mathrm{b}} \pm 1.32$ \\
Color & $4.06^{\mathrm{a}} \pm 1.17$ & $4.81^{\mathrm{a}} \pm 1.36$ & $4.03^{\mathrm{a}} \pm 1.59$ & $4.06^{\mathrm{a}} \pm 1.17$ \\
Aroma & $4.31^{\mathrm{a}} \pm 0.81$ & $4.50^{\mathrm{a}} \pm 1.20$ & $4.26^{\mathrm{a}} \pm 1.07$ & $4.38^{\mathrm{a}} \pm 1.32$ \\
Flavor & $4.66^{\mathrm{a}} \pm 1.05$ & $4.37^{\mathrm{a}} \pm 1.17$ & $4.12^{\mathrm{a}} \pm 1.34$ & $4.62^{\mathrm{a}} \pm 1.29$ \\
Texture & $4.06^{\mathrm{a}} \pm 0.93$ & $4.72^{\mathrm{a}} \pm 1.15$ & $4.75^{\mathrm{a}} \pm 1.39$ & \\
\hline
\end{tabular}

Values are given as mean $\pm \mathrm{SD}(\mathrm{n}=32)$. ${ }^{\mathrm{a}} \mathrm{Different}$ letter within the same row indicate significant difference ( $\left.\mathrm{p}>0.05\right)$. Control treatment - with no addition of ostrich meat; $\mathrm{T} 1$ - addition of $19.08 \%$ of ostrich meat; T2 - addition of $38.34 \%$ of ostrich meat; T3 - addition of $57.60 \%$ of ostrich meat.

lightness values between 43.29 and 52.68 , which increased with an increase in pressure, temperature and processing time (SUPAVITITPATANA; APICHARTSRANGKOON, 2007).

The red intensity $\left(a^{*}\right)$ (Table 2 ) is the most sensitive parameter for measuring color, red color characterization, and color stability (GARCÍA-ESTEBAN et al., 2003). According to Table 2, the $a^{*}$ values showed a slight variation during the first seven days, decreasing up to the end of processing. A possible explanation for the reduction in the $a^{*}$ values at the end of the process could be the partial denaturation of nitrosomyoglobin pigment due to lactic acid production (PÉREZ-ALVAREZ et al., 1999) or even lipid oxidation in meat products (FERNÁNDEZ-LOPEZ et al., 2003; YU et al., 2002). Similar results were obtained in other studies (KAYAARDI; GÖK, 2003; CAMPAGNOL et al., 2007a), in which the $a^{*}$ values of sausages increased during fermentation and decreased during maturation due to dehydration. At the end of processing, the treatment containing $38.34 \%$ of ostrich meat (T2) showed a more pronounced $(\mathrm{p}<0.05)$ instrumental red color than the others although these differences were visually imperceptible. This phenomenon is probably not related to the type of meat, but rather with the formation of a more stable nitrosomyoglobin (GÖK et al., 2011).

At Day 0, the sausages containing $57.60 \%$ of ostrich meat (T3) showed lower intensity yellow color $\left(b^{*}\right)$ (Table 2 ) than that of the other treatments, differing $(\mathrm{p}<0.05)$ from the control treatment and the treatment containing $19.08 \%$ of ostrich meat (T1). All treatments showed a decrease in yellowness towards the end of process, when only the treatments $\mathrm{T} 1$ and T2 were not significantly different. The changes in $b^{*}$ found during fermentation and maturation in the present study were also found in another study (DEMEYER; VERPLAETSE; GISTELINCK, 1986) on salami sausages, and they are probably due to the oxygen consumption by microorganisms during their exponential growth phase and the decrease in oxymyoglobin, which contributes to the $b^{*}$ values. Other authors reported that microorganisms produce metabolites that induce the oxidation of meat and fat present in the sausages (DEMEYER; VERPLAETSE; GISTELINCK, 1986; SARASIBAR; SPANCHEZ; BELLO, 1989), contributing to the decrease in this value.

The color saturation ( $C^{*}$ values) of T2 was significantly higher than that of the other treatments at Day 0 and Day 28 (Table 2). In accordance with the findings of another study (BOZKURT; BAYRAM, 2006), we also observed that the $C^{*}$ values decreased during the ripening period, which indicates that new pigments are formed during ripening.

The hue angle $\left(h^{\circ}\right)$ showed a different behavior in the different treatments. In the control treatment, the $h^{o}$ values decreased during fermentation and increased at the Day 14, followed by a decrease on the other subsequent days. In the treatments with ostrich meat, the $h^{\circ}$ values showed a slight variation, and at the end of the process, it showed a significantly difference compared to the control. Unlike the others, T3 showed a negative hue angle, which indicates a higher dark red nuance due to the highest myoglobin content present in this treatment (with higher amount of ostrich meat (57.60\%)). Both Chroma and Hue angle are based on $a^{*}$ and $b^{\star}$ values; therefore, the changes in these values are caused by the same reasons as those in $a^{*}$ and $b^{*}$.

\subsection{Sensory parameters}

The mean values of color, aroma, flavor, and texture are shown in Table 3. The parameters analyzed by the panelists ranged from "no difference from the standard" and "better than the standard", with no significant differences $(\mathrm{p}<0.05)$ for aroma, flavor, and texture. There was a significant difference only for color; the treatment with higher amount of ostrich meat (T3) showed lower values than those of the other treatments, ranging from "much worse than the standard" and "worse than the standard".

The sausages produced with the highest percentage of ostrich meat (T3) showed a lower average score for the parameter color than that of the other treatments. The intense red color, which is a characteristic of ostrich meat, does not depend on the muscle used for the product elaboration (SALES, 1996; BERGE et al., 1997). The treatment with $57.60 \%$ of ostrich meat (T3) obtained higher rejection by the panelists due to its high content of myoglobin.

This is due to the strong tendency towards brown in this treatment, thus indicating the need to use lower amounts of ostrich meat to increase consumer acceptability. The sensory values found in this study are in accordance with those of other studies on ostrich meat salami made with different starter cultures (BÖHME et al., 1996) and cured sausages made with rhea meat (CAMPAGNOL et al., 2007b). 


\section{Conclusions}

The use of ostrich meat affected the $L^{*}$ and $b^{\star}$ values, and the sausages were darker than the control. The products were well accepted by the panelists, except for the treatment containing $57.60 \%$ of ostrich meat, which showed lower scores regarding color. The treatment with $19.08 \%$ of ostrich meat was preferred by the panelists; therefore, it is the most appropriate for largescale manufacturing and launch in the market as an alternative for a healthy, innovative, and differentiated product.

\section{References}

ANSORENA, D. et al. Colour evaluation of chorizo de Pamplona, a Spanish dry fermented sausage: comparison between the CIE lab* and the Hunter Lab systems with illuminants D65 and C. Meat Science, v. 46, n. 4, p. 313-318, 1997. http://dx.doi.org/10.1016/ S0309-1740(97)00025-9

BARBUT, S. Effects of chemical acidification and microbial fermentation on the rheological properties of meat products. Meat Science, v. 71, n. 2, p. 397-401, 2005. PMid:22064242. http://dx.doi. org/10.1016/j.meatsci.2005.03.026

BARBUT, S. Color development during natural fermentation and chemical acidification of salami-type products. Journal of Muscle Foods, v. 21, n. 3, p. 499-508, 2010. http://dx.doi.org/10.1111/j.17454573.2009.00198.x

BARBUTI, S.; PAROLARI, G. Validation of manufacturing process to control pathogenic bacteria in typical dry fermented products. Meat Science, v. 62, n. 3, p. 323-329, 2002. http://dx.doi.org/10.1016/ S0309-1740(02)00124-9

BERGE, P. et al. Meat quality traits in the emu (Dromaius novahollandiae) as affected by muscle type and animal age. Meat Science, v. 45, n. 2 , p. 209-221, 1997. http://dx.doi.org/10.1016/S0309-1740(96)00040-X

BÖHME, H. M. et al. Production of salami from ostrich meat with strains of Lactobacillus sake, Lactobacillus curvatus and Micrococcus sp. Meat Science, v. 44, n. 3, p. 173-180, 1996. http://dx.doi. org/10.1016/S0309-1740(96)00083-6

BOZKURT, H.; BAYRAM, M. Colour and textural attributes of sucuk during ripening. Meat Science, v. 73, n. 2, p. 344-350, 2006. PMid:22062307. http://dx.doi.org/10.1016/j.meatsci.2006.01.001

CAMPAGNOL, P. C. B. et al. Salame elaborado com Lactobacillus plantarum fermentado em meio de cultura de plasma suíno. Food Science and Technology, v. 27, n. 4, p. 883-889, 2007a.

CAMPAGNOL, P. C. B. et al. A carne de ema (Rhea americana) na fabricação de salame tipo italiano. Revista Higiene Alimentar, v. 21 , n. 148 , p. $60-63,2007$ b.

CARBAJO, E. Producción de avestruces. Eurocarne, v. 139, n. 9, p. 123-137, 2005.

CHASCO, J.; LIZASO, G.; BERIAIN, M. J. Cured colour development during sausage processing. Meat Science, v. 44, n. 3, p. 203-211, 1996. http://dx.doi.org/10.1016/S0309-1740(96)00092-7

COOPER, R. G.; HORBANCZUK, J. O. Anatomical and physiological characteristics of ostrich (Struthio camelus var. domesticus) meat determine its nutritional importance for man. Animal Science Journal, v. 73, n. 3, p. 167-173, 2002. http://dx.doi.org/10.1046/ j.1344-3941.2002.00024.x

CURT, C. et al. A method for analysis and control of sensory properties during processing-application to the dry sausages process. Food Control, v. 15, n. 5, p. 341-349, 2004. http://dx.doi.org/10.1016/ S0956-7135(03)00084-7
DEMEYER, D. I.; VERPLAETSE, A.; GISTELINCK, M. Fermentation of meat: an integrated process. Food Chemical Biotechnology, v. 41, n. 1, p. 131-140, 1986.

DEMEYER, D. et al. Control of bioflavour and safety in fermented sausage: first results of a European Project. Food Research International, v. 33, n. 3-4, p. 171-180, 2000. http://dx.doi. org/10.1016/S0963-9969(00)00031-4

ERCOSKUN, H.; ÖZKAL, S. G. Kinetics of traditional Turkish sausage quality aspects during fermentation. Food Control, v. 22, n. 2, p. 165-172, 2011. http://dx.doi.org/10.1016/j.foodcont.2010.06.015

FERNÁNDEZ-LOPEZ, J. et al. Functional compounds from citrus byproducts and their application in meat products. Trends in Food Science \& Technology, v. 15, n. 3-4, p. 176-185, 2003. http://dx.doi. org/10.1016/j.tifs.2003.08.007

FISHER, P.; HOFFMAN, L. C.; MELLET, F. D. Processing and nutritional characteristics of value added ostrich products. Meat Science, v. 55, n. 2, p. 251-254, 2000. http://dx.doi.org/10.1016/ S0309-1740(99)00139-4

GARCÍA-ESTEBAN, M. et al. Optimization of instrumental color analysis in dry-cured ham. Meat Science, v. 63, n. 3, p. 287-292, 2003. http://dx.doi.org/10.1016/S0309-1740(02)00084-0

GÖK, V. et al. The effects of some natural antioxidants on the color, chemical and microbiological properties of sucuk (Turkish dryfermented sausage) during ripening and storage periods. Journal of Food Processing and Preservation, v. 35, n. 5, p. 677-690, 2011. http://dx.doi.org/10.1111/j.1745-4549.2011.00517.x

GONCALVES, B. et al. Effect of ripeness and postharvest storage on the evolution of colour and anthocyanins in cherries (Prunus avium L.). Food Chemistry, v. 103, n. 3, p. 976-984, 2007. http://dx.doi. org/10.1016/j.foodchem.2006.08.039

HOFFMAN, L. C.; MELLET, F. D. Quality characteristics of low fat ostrich meat patties formulated with either pork lard or modified corn starch, soya isolate and water. Meat Science, v. 65, n. 2, p. 869875, 2003. http://dx.doi.org/10.1016/S0309-1740(02)00293-0

HOFFMAN, L. C. et al. Physical and sensory meat quality of South African Black ostriches (Struthio camelus var. domesticus), Zimbabwean Blue ostriches (Struthio camelus australis) and their hybrid. Meat Science, v. 79, n. 2, p. 365-374, 2008. PMid:22062765. http://dx.doi.org/10.1016/j.meatsci.2007.10.022

KAYAARDI, S.; GÖK, V. Effect of replacing beef fat with olive oil on quality characteristics of Turkish soudjouk (sucuk). Meat Science, v. 66, n. 1 , p. $249-257,2003$. http://dx.doi.org/10.1016/S03091740(03)00098-6

MAJEWSKA, D. et al. Physicochemical characteristics, proximate analysis and mineral composition of ostrich meat as influenced by muscle. Food Chemistry, v. 117, n. 2, p. 207-211, 2005. http:// dx.doi.org/10.1016/j.foodchem.2009.03.100

MEILGAARD, M.; CIVILLE, G. V.; CARR, B. T. Sensory evaluation techniques. 3rd ed. Boca Raton: CRC PRESS; 1999. 416 p.

NASCIMENTO, R. S. et al. Linguiças frescais elaboradas com carne de avestruz: características físico-químicas. Ciência Rural, v. 42 , n. 1, p. $184-188,2012$. http://dx.doi.org/10.1590/S010384782012000100030

NGAPO, T. M.; WILKINSON, B. H. P.; CHONG, R. 1,5-glucono$\delta$-lactone-induced gelation of myofibrillar protein at chilled temperatures. Meat Science, v. 42, n. 1, p. 3-13, 1996. http://dx.doi. org/10.1016/0309-1740(95)00028-3

PÉREZ-ALVAREZ, J. Á. et al. Physicochemical characteristics of Spanish type dry-cured sausage. Food Research International, 
v. 32, n. 9, p. 599-607, 1999. http://dx.doi.org/10.1016/S09639969(99)00104-0

PICALLO, A. B. et al. Calidad de carne de ñandu. Revista de la Industria Cárnica Latinoamericana, v. 134, n. 1, p. 24-31, 2004.

SALES, J. Histological, biophysical and chemical characteristics of different ostrich muscles. Journal of the Science of Food and Agriculture, v. 70, n. 1, p. 109-114, 1996. http://dx.doi.org/10.1002/ (SICI)1097-0010(199601)70:1<109::AID-JSFA474>3.0.CO;2-G

SALES, J.; HORBANCZUK, J. Ratite meat. Worlds Poultry Science Journal, v. 54, n. 1, p. 59-67, 1998. http://dx.doi.org/10.1079/ WPS19980005

SARASIBAR, B.; SPANCHEZ, J. M.; BELLO, J. Influencia de nitratos y nitritos sobre la estabilidad del pimentón (Capsicum annum L.) y el desarrollo del color en chorizo de pamplona. Alimentaria, v. 19, n. 1, p. 19-23, 1989.

SORIANO, A. et al. Lipolysis, proteolysis, physicochemical and sensory characteristics of different types of Spanish ostrich salchichon. Meat Science, v. 75, n. 4, p. 661-668, 2007. PMid:22064031. http://dx.doi. org/10.1016/j.meatsci.2006.09.015
SUPAVITITPATANA, S.; APICHARTSRANGKOON, A. Combination effects of ultra-high pressure and temperature on the physical and thermal properties of ostrich meat (yor). Meat Science, v. 76, n. 3, p. 555-560, 2007. PMid:22061000. http://dx.doi.org/10.1016/j. meatsci.2007.01.007

TERRA, N. N. Apontamentos de tecnologia de carnes. São Leopoldo: UNISINOS; 1998. 216 p.

TERRA, N. N.; BRUM, M. A. R. Carne e seus derivados: técnicas de controle de qualidade. São Paulo: NOBEL; 1988. 121 p.

WROSLTAD, R. E.; DURST, R. W.; LEE, J. Tracking colour and pigment changes in anthocyanin products. Trends in Food Science \& Technology, v. 16, n. 9, p. 423-428, 2005. http://dx.doi.org/10.1016/j. tifs.2005.03.019

YU, L. et al. Rosemary extracts as inhibitors of lipid oxidation and color changes in cooked turkey products during refrigerated storage. Journal of Food Science, v. 67, n. 2, p. 582-585, 2002. http://dx.doi. org/10.1111/j.1365-2621.2002.tb10642.x 